$\begin{array}{lll}\text { Makalenin Türü / Article Type } & : \text { Araştırma Makalesi / Researh Article } \\ \text { Geliş Tarihi / Date Received } & : 25.01 .2019 \\ \text { Kabul Tarihi / Date Accepted } & : 10.09 .2019 \\ \text { Yayın Tarihi / Date Published } & : 31.12 .2019 \\ \text { doi https://dx.doi.org/10.17240/aibuefd.20xx.Xx.Xxxxx-Xxxxxx } & \underline{1}\end{array}$

\title{
COĞRAFYA BÖLÜMÜ ÖĞRENCİLERİNİN OKUMA ALIŞKANLIKLARI HAKKINDAKİ GÖRÜŞLERININ İNCELENMESİ
}

\author{
Ziya İNCE ${ }^{1}$ Vedat ŞAHİN ${ }^{2}$
}

ÖZ

Bireyler kendilerini geliştirmek, sosyal hayatta ilerlemek, topluma faydalı olmak ve zevk almak gibi sebepler ile okuma eylemini gerçekleştirirler. Böylece farklı amaçlar gerçekleştirilirken, bu etkinlik sayesinde geçmişte bilinç altında öğrenilen birçok konu pekişerek daha anlamlı hale gelir. Üniversitede okuyan öğrenciler de okudukları ve kendilerini geliştirdikleri müddetçe hem topluma hem de kendilerine katkı sağlayabilirler. Okuma için de öncelikle okuma alışkanlığının kazanılmış olması gerekir. Bu araştırma coğrafya bölümü lisans öğrencilerinin okuma alışkanlıkları hakkındaki görüşlerini tespit etmek amacıyla gerçekleştirilmiştir. $\mathrm{Bu}$ çalışma, nicel bir araştırma özelliğindedir. $\mathrm{Bu}$ amaçla literatür taramasından sonra hazırlanan anket formu, uzman görüşüne sunulmuş, yapılan değiş̧ikliklerden sonra 121 öğrenciye uygulanmıştır. Bu nedenle bu araştırmada lisans coğrafya öğrencilerinin genel okuma alışkanlıkları, coğrafya alan eserlerini okuma alışkanlıkları, kütüphane kullanım düzeyleri, cinsiyete ve sınıf seviyesine göre değişip değişmediği incelenmeye çalışılmıştır. Araştırmanın coğrafya bölümündeki öğrencilerin tamamının görüşlerini yansıtması için anket bütün sınıf seviyelerinden öğrencilere uygulanmıştır. Araştırma sonucunda coğrafya bölümü öğrencilerinin kitap veya dergi okuma konusunda zayıf kaldıkları, süreli yayınları az takip ettikleri, üniversitedeki ve şehirdeki kütüphaneleri kullanma konusunda yetersiz kaldıkları, bilimsel yayınları takip etmekte zorlandıkları sonucuna ulaşılmıştır.

Anahtar Kelimeler: Okuma alışkanlığı, coğrafya bölümü öğrencileri, öğrenci görüşleri, kütüphane kullanımı

\section{EXAMINATION OF THE GEOGRAPHY DEPARTMENT STUDENTS' OPINION ON THE READING HABITS}

\begin{abstract}
Individuals carry out reading activity for the reasons such as improving themselves, progressing in social life, being beneficial to society and enjoying themselves. Thus, while different goals are being realized, many subjects learnt unconsciously in the past become more meaningful by this activity. Students studying at the university can contribute to the society as long as they read and improve themselves. First of all, they should gain a reading habit. This research was carried out to determine the opinions of the level of reading habit of undergraduate students of the geography department. This study is a quantitative research. For this purpose, literature review was carried out and a questionnaire was prepared accordingly. It was presented to the expert for an opinion, necessary changes were made and applied to 121 students. In this study, we examine the general reading habits of geography students, their reading habits in geography field, their levels of library use, and whether it varies according to gender and grade level. The survey was applied to students from all grade levels to reflect the views of all the students in the geography department. As a result of the study, it was concluded that the students of the department of geography have low level of reading books or magazines, only small number of students follow periodicals, and they do not use of libraries at the university and in the city efficiently and have difficulty in following scientific publications.
\end{abstract}

Keywords: Reading habits, geography department students, student opinions, library use.

\footnotetext{
${ }^{1}$ Namık Kemal Üniversitesi Fen Edebiyat Fakültesi Coğrafya Bölümü Öğretim Üyesi, 누 http://orcid.org/0000-0001-7389-8083

${ }^{2}$ Namık Kemal Üniversitesi Fen Edebiyat Fakültesi Coğrafya Bölümü Öğretim Üyesi, 1ttp://orcid.org/0000-0002-5502-5219
} 


\section{GíRiş}

Okuma, yaşam boyu öğrenmenin gerçekleștirilmesi için gerekli olan bir edinimdir (Kuş, 2010). Gelişen toplumların gelişimlerini gösteren en önemli niteliklerden biri yüksek oranda okumadır. Bir toplumun okuma alışkanlığı düzeyi, aynı zamanda bilginin toplumsallaşma seviyesinin en belirgin işaretlerindendir (Yılmaz, 1998). Kişiler kendilerini geliştirmek, sosyal hayatta ilerlemek, topluma faydalı olmak ve zevk almak için daima okuma etkinliklerini gerçekleştirir. Bu sayede geçmişte bilinç altında öğrendiği sözcükler pekişerek daha anlamlı hale gelir. Böylece kișinin bilgi ve kelime dağarcığı geliştiği gibi kavrama kabiliyeti de artar. Alışkanlık bilim insanları tarafindan farklı şekillerde tanımlanmıştır. Güneş (2015, s. 21) alışkanlığı, genel olarak kullanma ile kolay alışılmış bir hal alan, bilinçli düşünmeyi ve dikkat toplamayı gerektirmeden yapılan öğrenilmiş bir tepki ya da davranış türü olarak tanımlarken, Demirel $(2010$, s.7) düzenli ve sürekli olarak kendini gösteren öğrenilerek edinilmiş yalın davranışlar olarak tanımlamaktadır.

Niteliği itibariyle hem bir amaç hem de bir araç olan okuma, zaman içinde ortaya çıkar ve ihtiyaçları karşılama açısından değer taşır (Balcı, 2016). Bireyler kendi ihtiyaçları, ilgi alanları ve kabiliyetleri doğrultusunda farklı türde yayınlar okumaktadır. Kimi teknoloji alanına ilgi duyarken kimisi doğal unsurlara, bir başkası ise duygusal formlara yönelir. $\mathrm{Bu}$ açıdan okunan yayının türü ve konusu kişisel faktörlerle de yakından ilişkilidir (Odabaş, Odabaş ve Polat, 2008).

Toplumların gelişiminde önemli rol oynayan okuma alışkanlıklarının farklı özellikleri gözlenmektedir. Okuma bir yönüyle alışkanlık değil, bir hayat felsefesidir. Çünkü okuma insanın niteliklerini artırdığından, okuma becerisi etkin hale getirdiğinde insan, farklı bakış açısının yanında birçok beceriye de sahip olabilmektedir (Yalman, Özkan ve Kutluca, 2013). Bu durum toplum içerisinde okumayı farklı amaçlara yönelten bireylerin olduğunu ve çok çeşitli nedenlerle insanlar, farklı kaynaklardan okuma yaptıklarııı göstermektedir. Diğer yönden insanda okuma vasfı, bazen eğitim sonucunda kazanılan bir özelliktir. Ancak bazen de okuma yeteneğinin edinilebilmesi için başlı başına özel bir eğitime ihtiyaç duyulur (Aytaş, 2005).

Bireyin ve toplumun okuma alışkanlığı ve okuma oranlarını görmek için çeşitli araştırmalar yapılmaktadır. Okuma araştırmalarına yönelik olarak bir okul ya da sınıfın alışkanlıklarını ölçmek için testler, envanterler, gözlemler ve kayıtların incelenmesi gibi çeşitli yollara başvurulmaktadır (Öncül, 2000, s. 820).

Okuma alışkanlıkları ile ilgili günümüzde birçok çalışma yapılmıştır. Bu çalışmalara göre dil gelişimi, zihinsel gelişim ve duygusal gelişim birlikte okuma alışkanlığından etkilenmektedir. Şanlıbaba ve Gümüş’ün (2014) üniversite öğrencilerinin kitap okuma alışkanlıklarına yönelik tutumlarının ve bu tutumları etkileyen faktörlerin belirlenmesine yönelik yaptıkları çalışmada kız öğrencilerin erkek öğrencilerden daha istekli olduğunu ortaya çıkarmıştır. Odabaş ve Polat'ın (2008) üniversite öğrencilerinin okuma alışkanlığı üzerine yaptığı çalışmada, yükseköğrenim boyunca öğrencilerin okuma becerisinde gelişme olduğunu, buna karşın öğrencilerin yeterli okuma alışkanlığına sahip olmadıkları sonucuna ulaşmıştır. Demir'in (2015) öğrencilerin okuma alışkanlıkları ve tutumları arasında cinsiyet ve öncesi eğitim durumları açısından farklılaşma olup olmadığına yaptığı çalışmada, üniversite öğrencilerinin okuma becerilerinin ve alışkanlıklarının geliştirilip çeşitlendirilmesinde programlı bir şekilde ortam ve destek sağlanması; yazın bilim, metin dil bilim, gösterge bilimi yöntem ve tekniklerinden yararlanılması; sanat eğitimine ağırlık verilerek estetik zevkin geliştirilmesi gerekliliği sonucu ortaya çıkmıştır.

Koçak ve arkadaşlarının, öğretmen adaylarının kitap okuma tutumlarının çeşitli değiş̧kenler açısından incelenmesi amacıyla yaptı̆̆ çalışmada araştırmaya katılan öğretmen adaylarının kitap okuma alışkanlığına yönelik tutumlarının cinsiyete göre anlamlı farklılık gösterdiği; bölüm, sınıf düzeyi ve gelir düzeyi değişkenlerine göre ise anlamlı farklılık göstermediği sonucu bulunmuştur (Koçak, Çermik, Polat, \& Şahin, 2016). Yılmaz'ın (2002) Ankara merkez ilçelerinde görev yapmakta olan ilköğretim öğretmenlerinin okuma ve halk kütüphanesi kullanma alışkanlıkları üzerine yaptığı çalışmada, yaşam boyu öğrenme sürecinde öğretmenlerin rollerini gerçekleştirmeleri, okumanın ve kütüphane kullanımının toplumsal yaygınlığa kavuşmasını sağlayacağını ileri sürmektedir.

Taşkesenlioğlu'nun (2013) ortaöğretim öğrencilerinin okuma alışkanlıkları hakkındaki çalışmasında, öğrencilerin önemli bir bölümünün düşük bir okuma kültürüne sahip olduğu, bunun ebeveynlerinin eğitim düzeyiyle ilgili olduğu ve ebeveynlerin eğitim seviyesi yüksekse öğrencide de paralel olarak okuma oranının yüksek olduğu görmüștür. Ayrıca kız öğrencilerin erkeklere oranla yeterli olmamakla beraber, okuma kültürüne daha fazla sahip olduklarını tespit etmiştir. Ayyıldız, Bozkurt ve Canlı'nın (2006) yaptığı çalışmada ise ögrencilerin okuma kültürü istenilen düzeyde olmasa da edebiyat dünyasından çok da uzak olmadıklarını tespit edilmiştir.

Alan yazında tespit edilen bu çalı̧̧malara göre okuma alışkanlığı ile ilgili olarak daha çok dil ve edebiyat alanında çalışmaların yapıldığı göze çarpmaktadır. Özellikle lisans düzeyindeki coğrafya bölümü öğrencilerine yönelik olarak yapılmış bir çalı̧̧ma yer almamaktadır. 


\subsection{Araştırmanın Amacı ve Önemi}

Okuma alışkanlıkların kazanılmış olması hem öğrenciler hem akademisyenler hem de toplumun diğer kesimleri için büyük önem arz etmektedir. Alan yazın taramasından görüleceği üzere ülkemizde okuma alışkanlıkları, okuma kültürü ve kütüphane kullanımının düşük seviyede olduğu göze çarpmaktadır. Bu konuda öğretmenler grubu, lisans öğrencileri grubu ve ortaöğretim öğrencileri gruplarında birçok araştırma yapılmış olmasına rağmen spesifik olarak sadece coğrafya öğrencilerine yönelik bir araştırma bulunmamaktadır. Coğrafya bölümü öğrencilerinin okuma alışkanlıklarının düzeyinin bilinmesi, onların daha sonraki akademik sahada ve sosyal hayattaki çalışmaları hakkında bir fikir edinebilmek açısından büyük önem taşır. Ayrıca lisans düzeyindeki almış oldukları coğrafya eğitimi dışında, kendilerini ne düzeyde geliştirdiklerini görmek içinde önemlidir. Bu nedenle bu araştırmada lisans coğrafya öğrencilerinin hem genel okuma alışkanlıkları hem de coğrafya alan eserlerini okuma alışkanlıkları incelenmeye çalışılmıştır. Bu hedefe yönelik olarak şu sorulara cevap aranmıştır.

1- Coğrafya bölümü öğrencilerinin okuma alışkanlıkları cinsiyete ve öğrenim gördükleri sınıf düzeyine göre anlamlı bir farklılık göstermekte midir?

2- Coğrafya bölümü öğrencilerinin genel okuma ve coğrafya alan eserlerini okuma alışkanlıkları ne düzeydedir?

3- Coğrafya bölümü öğrencilerinin kitap ve dergi okumaya yönelik olarak kütüphane kullanım düzeyleri nasildır?

\section{YÖNTEM}

Araştırma modeli, araştırma amacına uygun ve ekonomik olarak verilerin toplanması ve çözümlenebilmesi için gerekli koşulların düzenlenmesidir (Karasar, 2013 s.76). Bu çalışma, Fen Edebiyat Fakültesinde Coğrafya Bölümü öğrencilerinin okuma alışkanlıklarını incelemeyi hedefleyen nicel bir araştırma özelliğinde olmakla birlikte, anket ile elde edilmiş olan bilgilerin teyidi niteliğinde bir açık uçlu soruya yer verilerek, öğrencilerin okuma ile görüşlerini ifade etmeleri sağlanmıştır. Nicel araştırma, verilerin sayılar biçiminde olduğu ve bunların istatistiki teknikler kullanılarak analiz edildiği araştırmayı ifade eder (Yeşil, 2014). Araştırmada tarama yöntemi kullanılmış ve anket çalışması ile veri toplanmıştır.

\section{1.Örneklem}

Araştırmanın örneklemi Namık Kemal Üniversitesi, Fen Edebiyat Fakültesi, Coğrafya Bölümü’nde okuyan öğrenciler içinden basit tesadüfi örneklem yöntemine göre seçilmiş, 57'si kız $(\% 47,1)$ ve 64'ü erkek $(\% 52,9)$ olmak üzere toplam 121 öğrenci oluşturmaktadır. Basit tesadüfi örnekleme, ana kütleyi temsil edebilecek bir örnek büyüklüğünün belirlenip, bu sayı kadar örnek kütlenin tesadüfi olarak seçilmesidir (Küçük, 2016, 99). Örnekleme katılan öğrencilerin cinsiyete göre dağılımı Tablo.01'de gösterilmiştir.

\begin{tabular}{llcccc}
\hline \multicolumn{5}{l}{ Tablo 1. Araştırmaya Katılan Ö̆grencilerin Cinsiyet Özellikleri } \\
\hline \multirow{3}{*}{ Cinsiyet } & Frekans (f) & Yüzde (\%) & Geçerli Yüzde & Birikimli (\%) \\
\cline { 2 - 6 } & Kadın & 57 & 47.1 & 47.1 & 47.1 \\
& Erkek & 64 & 52.9 & 52.9 & 100.0 \\
\hline
\end{tabular}

Çalışmaya katılan öğrencilerin mezun oldukları okul türlerine göre bakıldığında büyük bir çeşitlilik gösterdiği, ülkemizdeki hemen bütün okul türlerinden (Anadolu Lisesi (42), Mesleki ve Teknik Anadolu Lisesi (26), Anadolu İmam Hatip Lisesi (18), Sosyal Bilimler Lisesi (14), Çok Programlı Anadolu Lisesi (13), Diğer (7) vs.) mezun öğrencinin bulunduğu görülmektedir.

Ankete katılan öğrencilerin \%32,2'si (39) birinci sınıf, \%28,9'u (35) ikinci sınıf, \%17,4'ü (21) üçüncü sınıf ve \%21,5'i (26) dördüncü sınıf öğrencilerinden oluşmaktadır.

Araştırmaya katılan öğrencilerin sınıf seviyelerine göre dağılımları Tablo.02'de gösterilmiştir.

\begin{tabular}{|c|c|c|c|c|c|}
\hline & & Frekans(f) & Yüzde (\%) & Geçerli Yüzde & Birikimli Yüzde \\
\hline \multirow{5}{*}{ Sinıf Seviyesi } & Birinci Sinıf & 39 & 32.2 & 32.2 & 32.2 \\
\hline & İkinci Sınıf & 35 & 28.9 & 28.9 & 61.2 \\
\hline & Üçüncü Sınıf & 21 & 17.4 & 17.4 & 78.5 \\
\hline & Dördüncü Sınıf & 26 & 21.5 & 21.5 & 100.0 \\
\hline & Toplam & 121 & 100.0 & 100.0 & \\
\hline
\end{tabular}




\subsection{Verilerin Toplanması}

Coğrafya bölümü öğrencilerinin okuma alışkanlıklarının incelendiği bu araştırmada, araştırmacılar tarafından geliştirilen ve iki bölümden oluşan beşli likert tipi bir anket uygulanmıştır. Demografik bilgilerin bulunduğu birinci bölümde; öğrencilere okudukları sınıf, cinsiyet, liseden mezun oldukları okul türü gibi sorular sorulmuştur. İkinci bölümde ise öğrencilerin okuma alışkanlıklarına yönelik düşüncelerinin alınmaya çalışıldığı anket soruları yer almaktadır.

Anket soruları hazırlanırken literatür taraması sonucu ulaşılan örnekler incelenerek, uzman görüşü de alınarak ve coğrafya konularına uyarlanarak 15 sorudan oluşan bir test hazırlanmıştır. Yapılan ön uygulamadan sonra beş sorunun diğer soruların kapsamında yer aldığı görülerek soru sayısı 10'a düşürülmüş ve bazı sorularda ise düzeltmelere gidilerek anket hazırlanmıştır. Anket soruları ile okuma alışkanlığı ölçülmeye çalışılmış ve görüşler beş düzeyde kategorize edilmiştir. Uygulanan anketin güvenirliğini ölçmeye yönelik olarak Cronbach's Alpha değeri tespit edilmek istenmiş ve SPSS 22 programı vasıtası ile güvenirlik analizi yapılmıştır. Araştırma maddeleri için Cronbach Alpha güvenirlik değeri .780 olarak tespit edilmiştir. Bu değer yapılan çalışmada uygulanan anketin güvenilir olduğunu göstermektedir. Zira Cronbach's Alpha değerinin 0,70 ve üstü olduğu durumlarda ölçeğin güvenilir olduğu kabul edilir (Durmuş, Yurtkoru ve Çinko, 2016, 89).

Araştırmada öğrencilerin kitap okuma ile ilgili görüş ve önerilerini almak için "okuma ile ilgili eklemek istediğiniz ayrıca bir husus var mı?” açık uçlu son bir soru eklenmiştir. Bu soruya verilen cevaplar, analiz edilerek çalışmada kullanılmıştır.

\subsection{Verilerin Analizi}

Toplanan verilerin analizinde SPSS for Windows 22.0 istatistik programı kullanılmıştır. Öğrencilerin okuma alışkanlıkları ile alakalı olarak nicel istatistiklerde frekans (f), yüzde (\%) ve ortalama değerleri kullanılmıştır. Verilerin analizinde ağılıklı ortalama tekniğinden yararlanılmıştır. Öğrencilerin okuma alışkanlıklarının, öğrenim gördükleri sınıf düzeylerine göre anlamlı bir farklılık gösterip göstermediğini tespit etmek için SPSS 22 programı kullanılarak ANOVA testi uygulanmıştır. Ayrıca araştırmaya katılan öğrencilerin cinsiyete göre aralarında bir farklılık olup olmadığını belirlemek, anket sonucundaki puan ortalamaları için $t$ testi uygulanmıştır.

\section{BULGULAR}

Araş̧ırma anketine öğrencilerin verdiği cevaplar SPSS programına girildikten sonra elde edilen veriler tablolara dönüştürülerek anlamlı hale getirilmiştir.

Tablo 3.

Puan ortalamalarına göre t-Test sonuçları

\begin{tabular}{ccccc}
\hline Cinsiyet & $\mathbf{N}$ & $\overline{\mathbf{x}}$ & SS & Shg \\
\hline Kadin & 57 & 2.7246 & .46225 & .06123 \\
Erkek & 64 & 2.8031 & .47542 & .05943 \\
\hline
\end{tabular}

Araştırmaya katılan kız ve erkek öğrencilerin anket sonucundaki puan ortalamaları arasında farklılık olup olmadığını belirlemek için $t$ testi uygulanmıştır. Okuma alışkanlıkları ile cinsiyetleri arasında anlamlı bir farkın olmadığı Tablo.3'e bakıldığında görülmektedir. Buna göre kız öğrencilerin ağılıklı ortalaması $X=2,72$ iken, erkek öğrencilerin $X=2,80$ ortalamaya sahip olmaları okuma alışkanlığının olumlu olduğu ve değerlerin birbirine yakın olduğunu göstermektedir.

\section{Tablo 4.}

Tek yönlü ANOVA testi sonuçları

\begin{tabular}{ccccc}
\hline Sınıf Seviyesi & $\mathbf{N}$ & $\overline{\mathbf{x}}$ & SS & Shg \\
\hline Birinci Sınıf & 39 & 2.5359 & .39569 & .06336 \\
İkinci Sınıf & 35 & 2.8114 & .49335 & .08339 \\
Üçüncü Sınıf & 21 & 2.9429 & .39188 & .08552 \\
Dördüncü Sınıf & 26 & 2.9077 & .48077 & .09429 \\
Toplam & 121 & 2.7661 & .46896 & .04263 \\
\hline
\end{tabular}

Araştırmada coğrafya bölümü öğrencilerinin okuma alışkanlıklarında, öğrenim gördükleri sınıf düzeylerine göre anlamlı bir farklılık olup olmadığını tespit etmek için ANOVA kullanılmıştır. Tablo.4'e bakıldığında; 3.sınıfların $(X=2,94)$, 4.sinıfların $(X=2,91), 2$.sinıfların $(X=2,81)$ ve 1.sinıfların $(X=2,53)$ ortalamalara göre siralandıkları görülür. $\mathrm{Bu}$ ortalamalara göre bütün sınıflarda okuma alışkanlıkları olumludur ve sinıflara göre okuma alışkanlığı puanları arasında anlamlı bir farklılık görülmemektedir. 
Tablo 5.

Coğrafya Bölümü Öğrencilerinin Bir Yılda Coğrafya İle İlgili Kitap Okuma Alışkanlıkları

\begin{tabular}{lcccc}
\hline & Frekans(f) & Yüzde $\mathbf{( \% )}$ & Geçerli Yüzde & Birikimli Yüzde \\
\hline 7'den az & 62 & 51.2 & 51.2 & 51.2 \\
7-14 aras1 & 41 & 33.9 & 33.9 & 85.1 \\
14-21 aras1 & 12 & 9.9 & 9.9 & 95.0 \\
21-28 aras1 & 2 & 1.7 & 1.7 & 96.7 \\
28'den fazla & 4 & 3.3 & 3.3 & 100.0 \\
Toplam & 121 & 100.0 & 100.0 & \\
\hline
\end{tabular}

Coğrafya bölümü öğrencilerinin bir yılda coğrafya ile ilgili kitap okuma alışkanlıklarını ele aldığımız birinci soruya verdikleri cevaplar Tablo.5'te görülmektedir. Tablodaki sonuçlara göre öğrencilerin \%51,2'si bir y1lda coğrafya ile alakalı 7'den daha az kitap okumaktadır. Ayrıca yine düşük bir seviye olan 7-14 arası kitap okuyanların oranı ise \%33,9'dur. Bu iki oran toplandığında öğrencilerin \%85,1'inin bir yılda çok az coğrafya ile ilgili kitap okuduklarını göstermektedir.

Tablo 6.

Coğrafya Bölümü Öğrencilerinin Bir Yılda Coğrafya İle İlgili Dergi Okuma Alışkanlıkları

\begin{tabular}{lcccc}
\hline & Frekans(f) & Yüzde (\%) & Geçerli Yüzde & Birikimli Yüzde \\
\hline 7'den az & 86 & 71.1 & 71.1 & 71.1 \\
7-14 aras1 & 25 & 20.7 & 20.7 & 91.7 \\
14-21 aras1 & 6 & 5.0 & 5.0 & 96.7 \\
21-28 aras1 & 3 & 2.5 & 2.5 & 99.2 \\
28'den fazla & 1 & .8 & .8 & 100.0 \\
Toplam & 121 & 100.0 & 100.0 & \\
\hline
\end{tabular}

Coğrafya bölümü öğrencilerinin bir yılda coğrafya ile ilgili dergi okuma alışkanlıklarının sorulduğu araştırmanın ikinci sorusunda öğrencilerin \%80’i bir yılda yediden daha az dergi okuduklarını ifade etmişlerdir. Çok düşük olan bu orana bir de 7 ile 14 arasında dergi okuyanların oranı eklendiğinde, coğrafya öğrencilerinin coğrafya ile ilgili dergileri okuma ve takip etmeme oranları \%92’ye ulaşmaktadır (Tablo.6). Öğrencilerin gelecekte mesleklerini icra ederken kendilerine büyük faydası dokunacak olan coğrafya dergilerini çok az okumaları dikkat çekici bir husus olarak karşımıza gelmektedir.

\section{Tablo 7.}

Coğrafya Bölümü Öğrencilerinin Bir Günde Tv İzleme ve Müzik Dinleme Süreleri

\begin{tabular}{lcccc}
\hline & Frekans(f) & Yüzde (\%) & Geçerli Yüzde & Birikimli Yüzde \\
\hline 1 saatten az & 25 & 20.7 & 20.7 & 20.7 \\
1-2 saat aras1 & 36 & 29.8 & 29.8 & 50.4 \\
2-3 aras1 & 26 & 21.5 & 21.5 & 71.9 \\
3-4 aras1 & 17 & 14.0 & 14.0 & 86.0 \\
4'ten fazla & 17 & 14.0 & 14.0 & 100.0 \\
Toplam & 121 & 100.0 & 100.0 & \\
\hline
\end{tabular}

Araştırmanın üçüncü sorusu olan Coğrafya bölümü öğrencilerinin bir günde tv izleme ve müzik dinleme süreleri Tablo.7'de görülmektedir. Öğrencilerin bu soruya verdikleri cevaplara göre, tv izleme ve müzik dinleme günlük ortalama bir saatten az diyenlerin oranı \%20,7 iken, 1-2 saat arasında olanlar \%29,8 dir. Öğrencilerinin bir günde tv izleme ve müzik dinleme bakımından 2 saatin altındakilerin toplam oranı \%50,4 iken, 2 saatten çok olanların oranı \%49,6 seviyesindedir. Bu rakamlar karşısında Coğrafya bölümü öğrencilerinin bir günde tv izleme ve müzik dinleme sürelerinin birbirine yakın olduğu ve orta seviye düzeyinde toplandığı görülmektedir. Ancak genel olarak ele alındığında öğrencilerin sadece \%14'ünün 4 saatten fazla tv izleme ve müzik dinlemeye zaman ayırdığı göz önüne alındığında, bu oranın düşük olduğu söylenebilir. Bu oranlar tablo 8,11 ve 12 ile kıyaslandığında öğrencilerin tv izleme ve müzik dinlemeye ayırdıkları zamanın, kitap ve dergi okumaya ayırdıkları zamandan daha fazla olduğu ortaya çıkmaktadır.

\section{Tablo 8.}

Coğrafya Bölümü Ö̆̆rencilerinin Bir Günde Coğrafya İle İlgili Konularda Bilgisayarda Harcadıklart Süre

\begin{tabular}{lcccc}
\hline & Frekans(f) & Yüzde (\%) & Geçerli Yüzde & Birikimli Yüzde \\
\hline 1 saatten az & 21 & 17.4 & 17.4 & 17.4 \\
1-2 saat aras1 & 37 & 30.6 & 30.6 & 47.9 \\
2-3 aras1 & 21 & 17.4 & 17.4 & 65.3 \\
3-4 aras1 & 19 & 15.7 & 15.7 & 81.0 \\
4'ten fazla & 23 & 19.0 & 19.0 & 100.0 \\
Toplam & 121 & 100.0 & 100.0 & \\
\hline
\end{tabular}


Araştırması yapılan diğer bir soru, coğrafya bölümü öğrencilerinin bir günde coğrafya ile ilgili konularda bilgisayar başında harcadıkları süreleri tespit etmek içindir. Bu konuda öğrencilerin bilgisayarda bir saatten az zaman harcadıklarını ifade edenlerin oran $\% 17,4$ iken, 1-2 saat arasında bilgisayar kullananların oranı \%30,6 ile en üst seviyededir (Tablo.8). Bu soruda öğrencilerin verdiği cevaplara göre durum genel olarak iki saatten az kullananlar ve iki saatten çok kullananlar şeklinde ikiye ayrılabilir. Bununla birlikte öğrencilerin \%19'u her gün 4 saatten bazla bilgisayar başında zaman harcamaktadır.

Tablo 9.

Coğrafya Bölümü Öğrencilerinin Bir Günde Coğrafya Dışındaki Konularda Bilgisayarda Harcadıkları Süre

\begin{tabular}{lcccc}
\hline & Frekans(f) & Yüzde (\%) & Geçerli Yüzde & Birikimli Yüzde \\
\hline 1 saatten az & 34 & 28.1 & 28.1 & 28.1 \\
1-2 saat aras1 & 32 & 26.4 & 26.4 & 54.5 \\
2-3 aras1 & 20 & 16.5 & 16.5 & 71.1 \\
3-4 aras1 & 13 & 10.7 & 10.7 & 81.8 \\
4'ten fazla & 22 & 18.2 & 18.2 & 100.0 \\
Toplam & 121 & 100.0 & 100.0 & \\
\hline
\end{tabular}

Tablo.9'de görüldüğü üzere coğrafya bölümü öğrencilerinin bir günde coğrafya dışındaki konularda bilgisayarda harcadıkları süre, coğrafya konularıyla ilgili bilgisayar kullanımına göre biraz farklılık göstermektedir. Bir saatten az kullananların oranı \%28,8 iken, 1-2 saat arasında kullananların oranı \%26,4'tür. Bu iki oranın toplamı \%54,5 seviyesinde olmakta ve katılımcıların yarısından fazlasına ulaşmaktadır (Tablo.9). Bu oranlar, coğrafya bölümü öğrencilerinin bilgisayar başında daha çok coğrafya ile ilgili konularda zaman geçirdikleri sonucunu ortaya çıkarmaktadır. Araştırmadan sonra öğrencilere bu durumun sebebi sorulduğunda "bu durum üzerinde öğrencilerin üniversite görmüş oldukları coğrafya dersleri ile ilgili ödev yapmalarının önemli payı olduğu" görülmüştür.

\section{Tablo 10.}

Coğrafya bölümü ögrencilerinin günde yürüyüss, spor ve gezi için harcadıkları süre

\begin{tabular}{lcccc}
\hline & Frekans(f) & Yüzde (\%) & Geçerli Yüzde & Birikimli Yüzde \\
\hline 1 saatten az & 35 & 28.9 & 28.9 & 28.9 \\
1-2 saat aras1 & 31 & 25.6 & 25.6 & 54.5 \\
2-3 aras1 & 28 & 23.1 & 23.1 & 77.7 \\
3-4 aras1 & 15 & 12.4 & 12.4 & 90.1 \\
4'ten fazla & 12 & 9.9 & 9.9 & 100.0 \\
Toplam & 121 & 100.0 & 100.0 & \\
\hline
\end{tabular}

Araştırmadaki diğer bir soru ile coğrafya bölümü öğrencilerinin günlük olarak yürüyüş, spor ve gezi için harcadıkları süre tespit edilmek istenmiştir. Bu amaç doğrultusundaki soruya öğrencilerin \%28,9'u bir saatten az zaman ayırdıklarını ifade etmiştir. 1-2 saat arasında yürüyüş, spor ve gezi için zaman ayıranların oranı \%25,6 iken, 2-3 saat arasında zaman ayıranların oranı \%23,1'dir (Tablo.10). Üç saatten fazla zaman ayıranların toplam oranı ise \%22,3’tür. Bu oranlar coğrafya bölümü öğrencilerinin yürüyüş, spor ve gezi gibi sosyal etkinliklere orta seviyede zaman ayırdığ göstermektedir. Bu oranlar tablo 8, 11 ve 12 ile kıyaslandığında öğrencilerin yürüyüş, spor ve gezi için harcadıkları sürenin, kitap ve dergi okumaya ayırdıkları zamandan daha fazla olduğu ortaya çıkmaktadır.

\section{Tablo 11.}

Cŏgrafya Bölümü Öğrencilerinin Cŏgrafya İle İlgili Kitap veya Dergi Gibi Kaynakları Okuma Stklıkları

\begin{tabular}{lcccc}
\hline & Frekans(f) & Yüzde (\%) & Geçerli Yüzde & Birikimli Yüzde \\
\hline Her gün & 5 & 4.1 & 4.1 & 4.1 \\
Birkaç günde bir & 27 & 22.3 & 22.3 & 26.4 \\
Birkaç haftada bir & 45 & 37.2 & 37.2 & 63.6 \\
Ayda bir & 37 & 30.6 & 30.6 & 94.2 \\
Hiç & 7 & 5.8 & 5.8 & 100.0 \\
Toplam & 121 & 100.0 & 100.0 & \\
\hline
\end{tabular}

Coğrafya bölümü öğrencilerinin, coğrafya ile ilgili kitap veya dergi gibi kaynakları okuma sıklıklarının incelendiği diğer bir soruda, öğrencilerin büyük çoğunluğu sık okumadıklarını ifade etmişlerdir (Tablo.11). Bu verilere göre öğrencilerin sadece $\% 4,1^{\prime}$, her gün coğrafya ile ilgili kitap veya dergi gibi kaynakları okuduklarını ifade etmektedir. Bu soruya birkaç haftada bir diyenlerin oranı $\% 37,2$ ve ayda bir olarak cevaplayanların oranı \%30,6 olarak tespit edilmiştir. Bu verilere göre, ayda bir cevabını veren öğrenci oranı en yüksek seviyede çıkmaktadır. Hatta coğrafya konuları ile ilgili hiç kitap ve dergi okumadığını ifade eden yedi öğrencinin olması, kitap okuma alışkanlığı bakımından üniversite düzeyinde bile, bu konu üzerinde durulması gerektiğini ortaya koymaktadir. 
Tablo 12.

Coğrafya Bölümü Öğrencilerinin Coğrafya İle İlgili Kitap veya Dergi Gibi Kaynakları Okumaya Ayırdıkları Süreyi Yeterli Bulmaları

\begin{tabular}{lcccc}
\hline & Frekans(f) & Yüzde (\%) & Geçerli Yüzde & Birikimli Yüzde \\
\hline Tamamen yeterli & 4 & 3.3 & 3.3 & 3.3 \\
Yeterli & 27 & 22.3 & 22.3 & 25.6 \\
Kismen yeterli & 28 & 23.1 & 23.1 & 48.8 \\
Az yeterli & 6 & 5.0 & 5.0 & 53.7 \\
Yetersiz & 56 & 46.3 & 46.3 & 100.0 \\
Toplam & 121 & 100.0 & 100.0 & \\
\hline
\end{tabular}

Çalışmada yer alan diğer bir soru, coğrafya bölümü öğrencilerinin coğrafya ile ilgili kitap veya dergi gibi kaynakları okumaya ayırdıkları süreyi yeterli bulup bulmadıkları konusundaki düşüncelerini tespit etmeye yöneliktir (Tablo.12). Bu soruda öğrencilerin yarıya yakını $(\% 46,3)$ kendisinin coğrafya ile ilgili kitap veya dergi için okumaya ayırdığı süreyi yetersiz bulmaktadır. Öğrencilerin bu soruya verdikleri cevapların oranlarına bakıldığında, \%23,1'i k1smen yeterli, \%22,3’ü yeterli ve \%3,3'ü tamamen yeterli olarak ifade ettiği görülmektedir. Bu durum, öğrencilerin bu durumdan rahatsız olduklarını, gelecekte düzeltmeye yönelik çaba içerisine girebilecekleri hususunda bir ipucu vermektedir. Ayrıca gerekli alt yapı ve özendirmeler yapıldığında öğrencilerin, okuma hususunda bu açıklarını gidermek isteyecekleri kanaatini uyandırmaktadır. Bu konuda anket soruları analizinden sonra öğrencilere, bu konu ile görüşleri, sınıf ortamında sorulduğunda, alınan cevaplardan da anlaşılmıştır. Ancak gerek kendilerinin yeterli düzeyde coğrafya kitap ve dergisine sahip olmamaları gerekse üniversitenin kütüphanesinin bu konuda yetersiz olması, bu konu önündeki engeller olarak ifade edilmiştir. Ayrıca öğrencilere yöneltilen diğer soru ile "kütüphanelerden ne ölçüde yararlandıkları" ile ilgili verilen cevapları bu durumu teyit etmektedir.

\section{Tablo 13.}

Coğrafya Bölümü Öğrencilerinin Coğrafya Iç̧erikli Kitap veya Dergi İçin Kütüphanelerden Ne Ölçüde Yararlandıkları

\begin{tabular}{lcccc}
\hline & Frekans(f) & Yüzde (\%) & Geçerli Yüzde & Birikimli Yüzde \\
\hline Her gün & 4 & 3.3 & 3.3 & 3.3 \\
Haftada bir & 24 & 19.8 & 19.8 & 23.1 \\
Ayda bir & 21 & 17.4 & 17.4 & 40.5 \\
Y1lda bir & 62 & 51.2 & 51.2 & 91.7 \\
Hiç & 10 & 8.3 & 8.3 & 100.0 \\
Toplam & 121 & 100.0 & 100.0 & \\
\hline
\end{tabular}

Coğrafya bölümü öğrencilerinin coğrafya içerikli kitap veya dergi için kütüphanelerden ne ölçüde yararlandıkları hakkındaki soruya verdikleri cevaplar dikkat çekicidir. Bu soruya verilen cevaplar içinde coğrafya ile ilgili kitap veya dergi için kütüphaneyi her gün kullananların oranı sadece \%3.3'te kalmıştır. Bu soruya haftada bir diyenlerin oranı \%19.8 ve ayda bir olarak cevaplayanların oranı \%17,4'tür (Tablo.13). Bu oranların toplamı $\% 40,5$ iken, yılda bir olarak ifade edenlerin oranı \%51,2 ve hiç kullanmayanların oranı \% $\%, 3$ 'tür. Bu oranlara göre coğrafya bölümü öğrencilerinin coğrafya içerikli kitap veya dergi için kütüphanelerden yararlanmaları beklenen seviyede değildir. Özellikle öğrencilerin yarısından çoğunun sadece yılda bir kez kütüphaneye, coğrafya ile ilgi bir kitap veya dergi için gitmeleri, öğrencilerin okuma alışkanlarının ötesinde, kütüphanenin içerik bakımından öğrencilere hitap etmenin çok uzağında olduğunu göstermektedir. Fen Edebiyat fakültesi Merkez kütüphanesinde coğrafya branşı ile alakalı eserler ile ilgili yaptığımız incelemede pek fazla eserin olmadığı görülmüştür. Bu nedenle de öğrenciler gerek araştırma yaparken gerekse ödevlerini hazırlarken internet ortamından yararlanmaktadır.

\begin{tabular}{|c|c|c|c|c|}
\hline & Frekans(f) & Yüzde (\%) & Gecerli Yüzde & Birikimli Yüzde \\
\hline Çok düşük & 4 & 3.3 & 3.3 & 3.3 \\
\hline $\mathrm{Az}$ & 2 & 1.7 & 1.7 & 5.0 \\
\hline Orta & 55 & 45.5 & 45.5 & 50.4 \\
\hline Yüksek & 39 & 32.2 & 32.2 & 82.6 \\
\hline Çok yüksek & 21 & 17.4 & 17.4 & 100.0 \\
\hline Toplam & 121 & 100.0 & 100.0 & \\
\hline
\end{tabular}

Okuma alışkanlığında etkili olan kitap ücretleri ile ilgili olarak, coğrafya bölümü öğrencilerinin coğrafya ile ilgili kitap ücretlerini ne ölçüde yüksek buldukları sorusunda elde edilen veriler Tablo.14'te gösterilmiştir. Tabloda görüldüğü üzere öğrenciler kitap ücretlerini orta seviyede bulmaktadır. Çok düşük bulanların oranı \%3.3, az bulanların oranı $\% 1.7$, orta bulanların oranı $\% 45.5$, yüksek bulanların oranı $\% 32,2$ ve çok yüksek bulanların 
oranı \% 17,4’tür. Bu durum Coğrafya bölümü öğrencilerinin okuma alışkanlıklarında kitap ücretlerinin etkisinin az olduğunu göstermektedir. Bununla birlikte coğrafya ile ilgili kitapların fiyatlarını yüksek ve çok yüksek bulanların oranının \%49,6 olmasını, kısmen öğrencilerin alım gücü ile açıklamak mümkündür.

Öğrencilere yöneltilen, okuma hususunda belirtmek istedikleri diğer hususları yazmaları ile ilgili kısımda, anket sonuçları ile örtüşen ifadeler tespit edilmiştir. Birçok öğrencinin cevap yazmış olduğu bu bölümde yazılanların da özeti niteliğinde olan iki metne yer verilmiştir.

Örneğin bir öğrenci; “Bölümümüz ile alakal,, okul kütüphanesi fazlasıyla yetersiz kalmaktadır. Gerek kütüphanenin küçüklüğü, oturacak yer bulamama sıkıntısı, gerekse kaynak yetersizliği bakımından sorun yaşamaktayız." şeklinde kütüphanenin yetersizliğini açıkça ifade etmiştir.

Bir diğer öğrenci ise; “Çok kitap okuma isteğim ve alışkanlı̆̆ım var ancak bölümün zor olması ve çok geniş bir bilimsel içeriğin olmasından dolayı kitap okumaya yeterli zamanı bulamıyorum. Bölüm ders kitapları dışında farklı alan kitapları okuma firsatı bulamıyorum." şeklindeki görüşü ile kitap okuma oranının düşük olması konusundaki yorumunu dile getirmiştir.

Görüldüğü üzere, öğrenciler kütüphanenin küçüklüğünü, kaynakların yetersizliğini, kütüphanede yer bulma konusunda sorun yaşadıklarını ifade etmişlerdir. Ayrıca kitap okuma isteği olanların da bölüm derslerine çalışmak ve ödev hazırlamak için harcadıkları zamanın fazlalığı nedeniyle, başka okumalar için firsat bulamadıklarını, belirtmişlerdir. Bu ve bunun gibi olumsuz durumlar coğrafya bölümü öğrencilerinin kitap ve dergi okuma oranlarının düşük olmasında etkili olduğu ortaya çıkmaktadır.

\section{TARTIŞMA ve SONUÇ}

Coğrafya bölümü öğrencilerinin genel olarak okuma düzeyleri ve coğrafya alanı ile ilgili eserleri okuma alışkanlık seviyeleri ve kütüphane kullanımına yönelik görüşlerinin incelendiği bu çalışmada önemli sonuçlara ulaşılmıştır. Çalışma sonucunda lisans düzeyinde eğitim gören katılımcıların okuma alışkanlığı ve kütüphane kullanımı seviyesinin düşük olduğu görülmüştür. Ayrıca çalışma sonucunda, coğrafya bölümü öğrencilerinin coğrafya ile ilgili çok az kitap veya dergi okudukları bulgusuna ulaşılmıştır. Bu araştırma ile elde edilmiş olan sonuçlar Taşkesenlioğlu'nun (2013) ortaöğretim öğrencileri ile yaptığı çalışma ile; Semerci'nin (2002) beden eğitimi öğrencileri ile yaptığı çalışma ile; Ayyıldız, Bozkurt ve Canlı'nın (2006) Türkçe öğretmenliği öğrencileri ile yaptığı çalışma ile; Can ve Karadeniz'in (2017) ortaöğretim öğrencileri ile yaptığı çalışma ile ve Toruk'un (2008) üniversite öğrencileri ile yapmış olduğu çalışmalar neticesindeki bulgularla örtüşmektedir. Dolayısı ile coğrafya bölümü öğrencileri, büyük oranda, üniversitedeki ders çalışmaları ve ödevleri dışında, zamanlarını okumaya ayıran öğrencilerden oluşmamaktadır.

Öğrencilerin kitap okuma oranlarında görülen düşük seviye, günlük tv izleme ve müzik dinleme oranlarında kısmen yüksek bir oranla kendini göstermektedir. Öğrencilerin yarıdan fazlası günlük iki saatten fazla bu faaliyetleri yaptıklarını ifade etmiştir. Ayrıca öğrencilerin yarıya yakınının zamanlarının önemli bir kısmının televizyon izleyerek, müzik dinleyerek ve bilgisayar ile meşgul olarak geçirdiklerini ifade etmişlerdir.

Coğrafya bölümü öğrencileri düşük kitap okuma oranları gibi gezi, yürüyüş ve spor aktivitelerine de harcadıkları zaman yüksek düzeylerde değildir. Bundan hareketle coğrafya bölümü öğrencilerinin kısmen statik bir yaşam sürdükleri ve bedensel aktivitelerinin kısmen yetersiz olduğu sonucuna varılmıştır. Nitekim gezi, yürüyüş ve spor için öğrencilerin yarıdan fazlasının, günde iki saatten az zaman ayırdıkları ve bu zamanın bir kısmının da doğal hayatın bir parçası olarak üniversiteye gelme ve alışveriş gibi faaliyetler esnasında geçtiği düşünüldüğünde, bilinçli ve programlı bir bedensel aktiviteye ayrılan zamanın düşük seviyede olduğu sunucuna varılmaktadır.

Coğrafya öğrencilerinin coğrafya ile ilgili kitap veya dergi gibi kaynakları okuma sıklığını daha çok haftada bir ve ayda bir olarak kendilerinin belirtmeleri, bu konuda zayıf olduklarını, fakat daha fazla kitap veya dergi okumaları gerektiğinin farkında olduklarını ortaya koymaktadır. Bu bağlamda coğrafya bölümü öğrencilerinin yaklaşık yarısı, okumaya ayırdıkları süreyi yetersiz görmektedir. $\mathrm{Bu}$ yönüyle öğrencilerin okuma alışkanlıklarının geliştirilmesi ve coğrafya ile ilgili kitap veya dergi gibi kaynaklara ulaşım olanaklarının artırılması gerekir. Diğer taraftan coğrafya öğrencilerinin okuma alışkanlıklarında önemli bir husus olan kütüphane kullanımı konusu, öğrencilerin okuma alışkanlıkları ile ilgili önemli bir eksiklik olarak karşımıza çıkmaktadır. Ayrıca öğrencilerin yarıdan fazlası kitap ve dergi okumak ve ödünç almak için ya hiç gitmemiş ya da yılda sadece bir kez kütüphaneye gitmiştir. Şanlıbaba ve Gümüş’ün (2014) çalışmasında da katılımcıların kütüphane kullanımı çok düşük seviyelerde yer almaktadır. Dolayısı ile Türkiye'de özellikle üniversite bünyelerinde yer alan akademik niteliğin ön planda olduğu kütüphanelerin, kitap ve diğer kaynak bakımından zenginleştirilmesi ve öğrencilerin kütüphanelerden faydalanmaları konusunda bilinçlendirilmesi gerekir. Bunun yanında kütüphanelerin alt yapısının yeterli düzeyde olması ve öğrencilerin rahatlıkla çalışabilecekleri ortamın 
oluşturulması gerekir. Diğer yönden okuma ve araştırma hevesi oluşturulamamış insanlar için, kütüphanelerin niteliğinin yüksek olup olmamasının da bir değeri olmayacaktır.

Okuma alışkanlıklarında etkili olan faktörlerden biri de kitap ve dergilerin ücretleridir. Coğrafya öğrencilerinin okuma alışkanlığında kitap ve dergilerin ücretlerinin yüksekliğinin kısmen etkili olduğu öğrencilerin verdiği cevaplardan ortaya çıkmaktadır. Nitekim öğrencilerin bir kısmı, kitap ücretlerini yüksek bulurken, bir kısmı ise düşük bulmaktadır. Ancak öğrencilerin \%45,5’lik kısmı kitap fiyatlarının yüksekliğini orta derecece olduğunu ifade etmiştir. Ancak yarıya yakının kitap fiyatlarını düksek veya çok yüksek bulması, öğrencilerin alım gücünün düşük olduğunu göstermektedir. Bu açıdan varılan bulgular Odabaş ve arkadaşlarının (2008) yaptığı çalışma ile örtüşmekte ve öğrencilerin önemli bir kısmının okumamalarındaki nedenler içinde ekonomik sorunların da yer aldığı sonucuna varılmaktadır. Bu konuda Yılmaz'ın (2002) yapmış olduğu çalışmada ise bizim bulguların aksine, okuma materyallerinin pahalı olması, okuma seviyesinin düşük olmasında önemli bir neden olarak tespit edilmiştir.

Araştırmanın sonuçlarından biri de coğrafya öğrencilerinin okuma alışkanlıkları ile cinsiyetleri arasında anlamlı bir farkın olmadığıdır. Kız öğrenciler ile erkek öğrencilerin okuma alışkanlığının olumlu olduğu ve değerlerin birbirine yakın olduğu gözlenmiştir. Sonuçların olumlu olması yönüyle Batur, Gülveren ve Bek'in (2010) yaptığ1 çalışma ile örtüşmektedir. Ancak Batur ve arkadaşları kız öğrencilerin okuma alışkanlığı konusunda daha iyi durumda olduğu sonucuna varmışlardır ki, çalışmamız bu yönüyle, bir farklılık görülmektedir.

Araştırma bulgularına göre coğrafya bölümü öğrencilerinin okuma alışkanlıklarının öğrenim gördükleri sınıf seviyeleri itibariyle anlamlı bir farklılık göstermemektedir. Nitekim Anova testi verilerine göre bütün sınıflar küçük farklar ile birbirine yakın sonuçlar göstermektedir.

Sonuç olarak coğrafya bölümü öğrencilerinin kitap ve dergi okuma konusunda zayıf kaldıkları, süreli yayınları ve dergileri az sayıda takip ettikleri, üniversitedeki ve şehirdeki kütüphaneleri kullanmada yetersiz kaldıkları ve bilimsel yayınları takip etmekte zorlandıkları sonucuna ulaşılmıştır.

\section{5.ÖNERILLER}

Üniversiteler eğitim ve öğretimin en üst seviyesidir. Bu sebeple toplumların gelişiminde önemli rol oynamaktadırlar. Üniversitede okuyan öğrenciler okudukları, kendilerini geliştirdikleri müddetçe hem topluma hem de kendilerinin mesleki alandaki başarına katkı sağlayabilirler. Bu önemli konuda öğrencilerin okuma alışkanlıklarının gelişmesi şu öneriler getirilebilir.

- Okuma alışkanlıkları ailede ve okulun ilk yıllarında başladığı için ailelerin ve ilkokul öğretmenlerinin çocukların kitap okuması konusunda duyarlıklarının artırılması. Böylece yüksek öğretime geçen öğrencilerin okuma düzeyleri de artmış olacaktır.

- Üniversite düzeyinde de olsa öğrencilerin okumaya yönelik teşvik edilmesi ve okuma kültürünün geliştirilmesi,

- Öğrencilerin, tv izleme ve müzik dinleme gibi boş zamanlarını geçirmek için harcadıkları zaman ile kitap okumaya ayırdıkları zamanı dengeleme konusunda bilinçlendirilmesi,

- Kütüphanelerdeki kitapların sayısının artırılması ve kütüphane ortamının öğrencilerin ilgisini çekecek tarzda düzenlenmesi gerekir. Öğrencilerin ilgileri, eğilimleri, ihtiyaçları göz önüne alınarak kütüphanelerin zenginleştirilmesine ihtiyaç vardır. Ayrıca coğrafya eserleri konusunda kütüphanelerin zenginleştirilmesi ile coğrafya bölümü öğrencilerinin okuma alışkanlıklarının artacağı düşünülmektedir. 


\section{KAYNAKÇA}

Aytaş, G. (2005). Okuma eğitimi. Türk Ĕgitim Bilimleri Dergisi,3(4), 461-470.

Ayyıldız, M., Bozkurt, Ü. ve Canlı, S. (2006). Okuma kültürü üzerine bir araştırma. Milli Eğitim Dergisi, 34(169).

Balcı, A. (2016). Okuma ve anlama eğitimi. Ankara: Pegem Akademi.

Batur, Z., Gülveren, H. Ve Bek, H. (2010). Öğretmen adaylarının okuma alışkanlıkları üzerine bir araştırma: uşak eğitim fakültesi örneği. Uşak Üniversitesi Sosyal Bilimler Dergisi 3(1), 32-49.

Can R., Karadeniz A., (2017) Ortaöğretim Öğrencilerinin Okuma Alışkanlıkları Üzerine Bir Araştırma (Kırşehir İli Örneği) Akademik Sosyal Araştırmalar Dergisi, Yı1: 5, Sayı: 55, Sf. 75-91

Demir, S. (2015). Üniversite öğrencilerinin okuma tutum ve alışkanlıkları üzerine bir değerlendirme. Uluslararası Türkçe Edebiyat Kültür Eğitim Dergisi Sayı: 4(4), 1657-1671.

Demirel, Ö. (2012). Ĕ̆itim sözlüğü. Ankara: Pegem Akademi.

Durmuş, B., Yurtkoru, E. S. ve Çinko, M. (2016). Sosyal bilimlerde ssps ile veri analizi. İstanbul: Beta Yayıncilik.

Güneş, H. (2015). Eğitim bilimleri terimleri sözlüğü. Ankara: Ütopya Yayınevi.

Karasar, N. (2013). Bilimsel araştırma yöntemi. (25. Basım). Ankara: Nobel Akademik Yayıncılık,

Koçak, B., Çermik, F., Polat, S. ve Şahin, N. (2016). Öğretmen adaylarının kitap okuma tutumlarının çeşitli değişkenler açısından incelenmesi. Uluslararası Türkçe Edebiyat Kültür Eğitim Dergisi, 5(1), 395411.

Kuş, Z., Türkyılmaz, M. (2010). Sosyal Bilgiler ve Türkçe öğretmeni adaylarının okuma durumları: (ilgi, alışkanlık ve okuma stratejilerini kullanım düzeyleri), Türk Kütüphaneciliği, 24, 1, 11-32.

Küçük,O. (2016). Bilimsel araştırma yöntemleri, Bursa: Ekin Yayınevi.

Odabaş, H., Odabaş, Z., \& Polat, C. (2008). Üniversite öğrencilerinin okuma alışkanlığı: ankara üniversitesi örneği. Bilgi Dünyası, 9(2), 431-465.

Öncül, R. (2000). Eğitim ve eğitim bilimleri sözlüğ̈̈. İstanbul: Milli Eğitim Bakanlığı Yayınları.

Semerci, Ç. (2002). Türk üniversitelerinde beden eğitimi ve spor bölümü öğrencilerinin okuma alışkanlıkları. Ĕgitim ve Bilim, 27(125), 36-43.

Şanlıbaba, P. ve Gümüş, E. (2014). Okuma alışkanlıkları üzerine bir araştırma: ankara üniversitesi kalecik meslek yüksekokulu örneği. Elektronik Mesleki Gelişim ve Araştırmalar Dergisi 2(3), 44-50.

Taşkesenlioğlu, L. (2013). Ortaöğretim öğrencilerinin okuma alışkanlıkları üzerine bir inceleme. Karadeniz Sosyal Bilimler Dergisi, 9, 30-40.

Toruk, İ. (2008). Üniversite gençliğinin medya kullanma alışkanlıkları üzerine bir analiz. Selçuk Üniversitesi Sosyal Bilimler Enstitüsü Dergisi, 19, 475-488.

Yalman, M., Özkan, E. ve Kutluca, T. (2013). Eğitim fakültesi öğrencilerinin kitap okuma alışkanlıkları üzerine betimsel bir araştırma: Dicle Üniversitesi Örneği. Bilgi Dünyası Dergisi, 14 (2), 291-305.

Yeşil, R (2014). Nicel ve nitel araştırma yöntemleri, Remzi Y. Kılcal(Ed.), Bilimsel Araştırma Yöntemleri içinde, s. 51-80, Ankara: Nobel Yayıncilık.

Yılmaz, B. (1998). Okuma alışkanlığı sorunu, bir enstitü örneği ve Türkiye için öneriler. Türk Kütüphaneciliği, $12(3)$.

Yılmaz, B. (2002). Ankara'daki ilköğretim öğretmenlerinin okuma ve halk kütüphanesi kullanma alışkanlıkları üzerine bir araştırma. Türk Kütüphaneciliği, 16(4), 441-460. 


\section{EXTENDED ABSTRACT}

\section{Introduction}

Reading habits play an important role in the development of societies and have different characteristics. In some ways, reading is not a habit but a philosophy of life. Reading improves the qualities of the people, and when the reading skill is gained, the individual can have different perspectives and also acquire many different skills (Yalman, Özkan and Kutluca, 2013). There are individuals who read for different purposes and read from different sources for a variety of reasons. On the other hand, reading sometimes gained as a result of education. However, sometimes a special training is required to gain reading skills (Aytaş, 2005). The studies of Koçak et al. (2016), Yılmaz (2002), Taşkesenlioğlu (2013), Ayyıldız, Bozkurt and Canlı (2006) are important in this area.

After the literature review, it is seen that most of the studies about reading habits were related to the field of language and literature. In particular, there is no study conducted about geography students at the undergraduate level. It is important to know the level of reading habits of geography students in order to understand their future academic works or their activities in social life. It is also significant to see their level of self-improvement apart from the geography education which they receive at undergraduate level. Therefore, in this study, we examine the general reading habits of geography students, their reading habits in geography field, their levels of library use, and whether it varies according to gender and grade level.

\section{Method}

This study is a quantitative research aiming to examine the reading habits of geography students of the Faculty of Arts and Science. However, the survey includes an open-ended question to confirm the information obtained by the questionnaire. Quantitative research refers to a study in which data consist of numbers and analysed by statistical techniques (Yeşil, 2014). In this study, screening method was used and a survey was carried out. It was aimed to examine the geography department students' opinion on reading habits.

The sample of the study consist of 121 students, 57 of them are females and 64 of them are males and they were chosen by simple random sampling method amongst the students of Geography Department of Faculty of Arts and Sciences of Namık Kemal University.

In this study, reading habits of geography students were examined and the survey participants subjected to fivepoint Likert scale questionnaire with two sections, which was developed by the researchers. The Cronbach Alpha reliability value of the questionnaire is specified as .780. and it shows that the questionnaire is reliable. Because it is accepted that if the Cronbach's Alpha value is 0.70 and over, the scale is considered to be reliable (Durmuş, Yurtkoru and Çinko, 2016, 89).

SPSS 22.0 statistical program for Windows was used to analyze the data. Frequency (f), percentage (\%) and mean $(\mathrm{X})$ values were used in quantitative statistics related to students' reading habits. ANOVA test was used to determine whether students' reading habits differed significantly according to their grade levels, and t-test was applied to determine whether there was a difference between them according to gender.

\section{Findings, Discussion and Results}

This study examines whether general reading habits of undergraduate geography students or their reading level in geography field or and their attitude towards library use differ according to grade or gender variables. As a result of the study, it has been concluded that the level of reading habits and library use of the undergraduate students was low. Furthermore, it was seen that the students of the geography department read only very few books or journals about geography. Therefore, it is concluded that the geography students do not spend time for reading, except the reading for course works and assignments.

Although the level of students' reading was very low, their level of daily TV watching and listening to music were quite high. More than half of the students stated that they carried out these activities more than two hours daily. In addition, female students' tendency to watch television and listening to music is higher than that of male students and almost half of the students spent significant time by watching television and listening to music.

Similar to low level of reading habits of geography department students, their time spent on travel, hiking and sport activities are also at the low level. Thus, it was concluded that the students of the geography department have quite static life and their physical activities were relatively insufficient. As a matter of fact, more than half of the students stated that they spend less than two hours a day for travel, hiking and sport, and some of this time 
is spent during daily activities such as going to the university or shopping. Therefore, it can be said that the time devoted to a conscious and programmed physical activity is low.

The geography students state that the frequency of reading books or journals about geography once a week and once a month, but they are aware of the fact that they are weak in this subject but need to read more books or magazines. In this context, about half of the students in the department of geography consider the time they devote to reading is not sufficient. In this respect, it is necessary to improve the reading habits of the students and increase the possibilities of access to resources such as books or journals related to geography. On the other hand, the low level of library use is an important issue in geography students 'reading habits,

Moreover, more than half of the students never went to the library to read or borrow books and magazines or they did it only once a year. Therefore, especially the university libraries in Turkey, where academic resources available, should be enriched by the other books and resources and the awareness of the students should be raised about the benefits of the library. In addition, the libraries should have necessary facilities and provide an environment where the students can study easily. However, if the people do not have enthusiasm for reading and research, even the high quality of libraries will not be of any value.

One of the factors influencing reading habits is the price of books and magazines. It is revealed that the price of books and magazines partly affect the reading habits of geography students. However, although some of the students find book prices quite high but some find it quite low. Yet, $45.5 \%$ of the students stated that the book prices were moderately high. The fact that, nearly half of the students stated that book prices were high or very high also shows that the purchasing power of students is quite low.

According to the findings of the research, the reading habits of geography students did not show a significant difference according to their grade or gender. As a matter of fact, according to the Anova test and t-test, all grades show similar results with small differences.

It has been concluded that the level of reading habits students of geography about is quite low and their frequency of reading books or following magazines or their use of university and city libraries are insufficient, and they find it difficult to follow scientific publications. 